\title{
Intermediaries, Financial Markets and Growth: Some more International Evidence
}

\author{
António Afonso, ${ }^{* 1}$ Raquel Ferreira, ${ }^{* 2}$ Edmund Freitas, ${ }^{* 3}$ Celso Nóbrega, ${ }^{* 4}$ \\ and José Pinheiro ${ }^{* 5}$
}

December 2002

\begin{abstract}
We examine how financial institutions affect growth, taking into the account the organisational features of the financial system namely systems characterised by strong financial intermediaries and systems where the financial markets assume a more important role. We use a panel of 24 developed and developing countries over the 70 s, $80 \mathrm{~s}$ and 90s, to evaluate the existence of possible links between the type of preponderant financial system (bank-based or more capital markets based) and economic growth.
\end{abstract}

JEL: C23; G20; O40

KEYWORDS: Financial system; Economic growth; Panel analysis.

\footnotetext{
* ISEG/UTL - Technical University of Lisbon, R. Miguel Lúpi 20, 1249-078 Lisbon, Portugal.

${ }^{1}$ CISEP - Centre for Research on Portuguese Economics, ISEG/UTL. Corresponding author, email: aafonso@iseg.utl.pt.

2 email: raquelferreira78@hotmail.com.

3 email: efreitas@cotavalor.pt.

4 email: celso.nobrega@cgd.pt.

5 email: jmp@ renova.pt.
} 


\section{Contents}

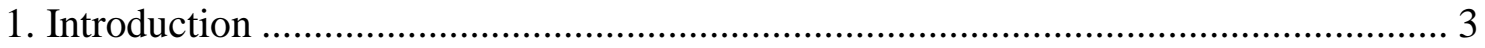

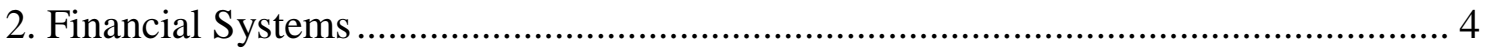

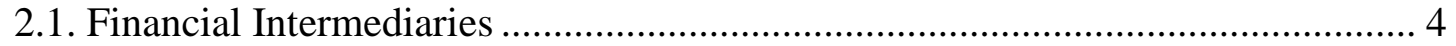

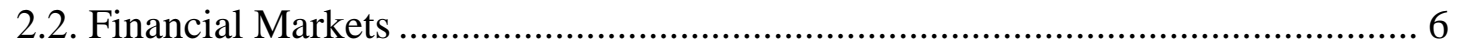

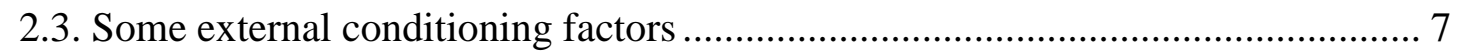

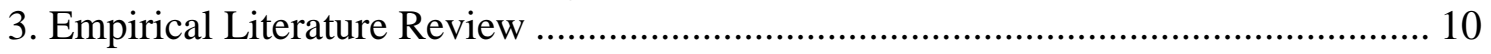

4. Panel Analysis: Financial Intermediaries versus Capital Markets ............................ 12

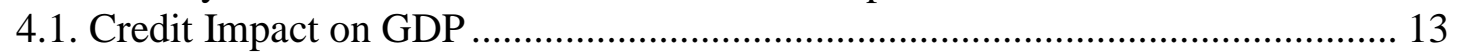

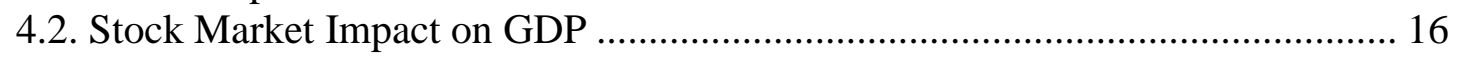

4.3. Credit and Stock Market Capitalisation Impact on GDP Growth ...................... 19

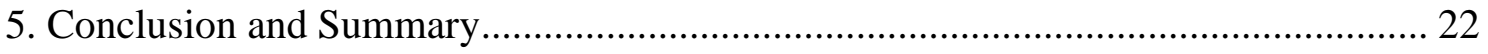

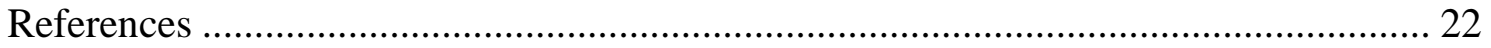

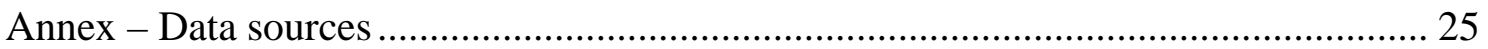




\section{Introduction}

Different models of financial systems coexist in modern economies. Allen and Gale (2000) broadly classify financial systems as systems of "German type," where financial intermediaries dominate, and systems of "American type," where financial markets are more predominant. For instance, the euro area financial system might be characterised as a bank-based system given the important role of banks in the majority of the countries. The US is the more straightforward case of a market-based financial system.

However, these differences are always somehow relative for a given country. Also, financial systems do evolve over time, generally towards the increase and complexity of financial operations and services offered to the economic agents. In other words, the trend seems to be an increase in the development of financial markets and financial innovation, even if financial intermediaries remain the main providers of funds for households and enterprises.

Recent literature stresses the importance of the coexistence of the two types of systems in a single economy. Stulz (2000) suggests that the existence of developed financial markets allows the banks, as investors, to limit its exposure to some economy sectors, therefore reducing its operating risk levels. The coexistence of financial intermediation and developed financial markets tends to increase the competition among financial systems in an economy, leading to reductions in the transaction costs that enable increased investment rentability. Thiel (2001) underlines the importance of the adaptation and evolution of financial systems in order to satisfy the economic needs. For instance, the role of venture capital in stimulating investment in risky economic sectors, which frequently also possess a large growth potential.

In this paper we use a panel data approach to examine the role financial systems play in economic growth. The paper adds to the existing literature by dividing the country sample into three groups, according to the so-called "predominant" financial system: bank-based systems; financial markets based systems and also a third group of inbetween financial systems. 
The remainder of the paper is organised as follows. The next section discusses the main characteristics, and advantages of financial intermediaries and financial markets, namely concerning financial systems development. Section three briefly reviews the existent evidence on the financial system-growth relation. Section four is devoted to the panel data analysis of the aforementioned relationship for a sample of 24 developed and developing countries. Section five concludes the paper.

\section{Financial Systems}

For the majority of the countries, the usual way of financing economic activity still is through financial intermediaries, either monetary and financial institutions or insurance companies and pension funds. Nevertheless, the value of non-intermediated assets, through the bond and the stock market, has been rising and in some countries already accounts for a substantial share of GDP, higher than the value of intermediated assets. ${ }^{6}$ One may consider as examples of intermediated assets deposits, investment fund shares and technical reserves, and as intermediated liabilities loans granted by the intermediaries. Also, one can think about securities and listed and non-listed shares as non-intermediated assets, while indirect financing to the economy is broadly carried through bonds and shares and other equity.

\subsection{Financial Intermediaries}

Economic literature identifies five different mechanisms through which financial intermediation can have effects on economic growth. i) efficient allocation of financial resources; ii) the mobilisation of savings; iii) the reduction of information costs; iv) the reduction of supervision costs in investment projects, and v) the diversification of risks (specific risks, external shocks and inter-generational risks).

Greenwood and Javanovic (1990), point out the role of financial intermediaries as selectors of investment projects, the selection of more profitable projects resulting from the evaluation of the more favourable risk/return project rates. The existence of specific selection criteria theoretically originates a better allocation of financial resources in an

\footnotetext{
${ }^{6}$ This is for instance the case of the euro area in 2000 (see ECB (2002)).
} 
economy. However some authors have also illustrated cases where systematic financing from banks can lead to the development of non-profitable investments or even investment projects that generate losses over long periods of time.

Tsuru (2000) suggests that an excessive proximity between banks and companies can reduce the cost of capital but also generate investment in projects, which lack capacity to generate profit in an acceptable time frame. Indeed, Stiglitz (1985) has long identified cases where a rise in interest rates can lead to adverse selection problems, a situation where banks are led to select investment projects with high levels of risk. These two types of problems - moral hazard derived from excessive proximity between banks and companies and adverse selection - can hamper the ability of financial intermediaries in conducting a sound investment selection, thus reducing the allocation efficiency of financial resources.

The mobilisation of savings, the second identified transmission mechanism, acts as the main source of resources through which financial intermediaries are able to channel funds for investment, as mentioned for instance by Sirri and Tufano (1995). This capacity tends to increase the overall rate of profitability of capital in an economy.

As stated by Levine (1997, 1999), financial intermediaries have the capacity of reducing the information gathering costs associated to the development of investment projects. A reduced number of financial intermediaries can therefore collect the necessary information to implement and develop new investment projects. Otherwise, each investor, individual or institutional, would have to invest primarily in gathering its necessary information, what would be a more costly and time-consuming process. Sharpe (1990) also mentions, as a positive aspect of the proximity between banks and companies that additional reductions regarding the costs of information can be achieved whenever there is satisfactory information symmetry between the two parties involved.

Financial intermediaries also have an important control role, by assuming the responsibility of being well informed and updated about the projects to which financing is directed. This delegated monitor role is already well explained in the literature. Additionally, Dewatripont and Maskin (1995) claim that the monitoring and postfinancing discipline are somewhat less demanding when conducted by financial 
intermediaries, in comparison with financial markets. Also, financial intermediation allows for inter-temporal risk smoothing, which constitutes part of the defensive mechanism of an economy to external and multi-annual shocks. This process originates from the management of provisions and bank reserves in the long run.

\subsection{Financial Markets}

Financial markets allow investors to directly diversify its investment portfolio and to select the level of risk exposure in accordance with its inherent risk aversion characteristics. ${ }^{7}$ However, financial markets do not allow for intergeneration risk sharing, since different generations participate in the market at different times (see on this topic Qi (1994) and Fulghieri and Roveli (1998)).

Despite this shortcoming, financial markets have several characteristics that play an important and positive role in economies and growth. As an example, one can mention the financing of a substantial number of projects that was performed through financial markets at least since the industrial revolution of the nineteenth century. Allen and Gale (2000) and Thiel (2001) mention the proven capacity of financial markets, particularly in the US, to finance new economic sectors, of which telecommunications, media and technology are examples.

By aggregating a vast set of opinions and expectations, financial markets have a role in distributing and reassigning the risk of the underlying assets amongst a large number of investors, which would otherwise have no contact with the projects they end up financing. The mobilisation of resources depends upon the degree upon which investors decide to assume long positions in the financial assets typically available through financial markets, as well as on the attractiveness of the market capitalisation evolution over time. In countries where financial markets are sufficiently developed and play an important role, such as in the United Kingdom or the United States, this mobilisation effectively seems to occur.

\footnotetext{
${ }^{7}$ See Allen and Gale $(1995,2000)$ for an in depth comparison between the role of financial intermediaries and financial markets.
} 
Also, financial markets often enable the development of compensation models that establish a relation between operational performance and management compensation schemes. Thus, companies have an incentive to link management compensation to performance, and managers an incentive to increase capital profitability.

As to the costs of information gathering, financial markets appear to be in disadvantage since information is gathered through more agents than in a financial system that relies more intensively on intermediaries. However, stock market quotation evolution can assume a monitor-type role. Another topic associated to an efficient financial resource allocation enabled by financial markets is acquisitions and mergers, and an active control market that seems more widespread and developed whenever financial markets have an important degree of development and dimension.

\subsection{Some external conditioning factors}

It is worthwhile to mention some factors that, given its contours, may considerably influence not only the development of financial systems but also the mechanisms through which financial systems influence economic growth, and even the way economic growth occurs, regarding the specialisation of economies. The interpretation of results of econometric studies having by focus macro-economic variables, such as the results presented in this paper, may well be incomplete without having in consideration the influence of other sort of factors. This why we think it is helpful to summarise here some of the most relevant insights emerged from this type of research.

Several authors, such as Carlin and Mayer $(1999,2002)$ and Levine, Loayza and Beck (2000) offer detailed studies of the interaction between financial systems and economic growth by analysing exogenous factors that bound the transmission mechanisms, such as legislative structure and country specific company ownership characteristics. Franks and Mayer (1962) had already reported the main differences of ownership concentration between the US and UK, as well as between these countries and France or Germany. They noted that in the US and in the UK a large and relevant portion of companies have its performance evaluation linked to the stock market performance of its stock, and its ownership dispersed by a large number of institutional or private investors. In France and Germany the number and importance of companies present in the stock markets is 
not as impressive as in the US or UK. In these two countries ownership concentration is much more the rule, large block-holdings of stocks belonging to institutional investors or families, rather than to a multitude of small investors. Japan has a "mixed" system, both phenomena being observed as to ownership structure and stock markets importance is concerned.

One good reason to consider this type of analysis regards the finding that ownership concentration systems, such as they occur in France and Germany, seem to be more compatible with investments that aim to expand the core businesses of companies, or with diversification processes into "well know ground." This is more common than rather having investments destined to more risky and exploratory activities, such as those frequently associated to state-of-the-art technologies or virtually new, emergent and unexplored business sectors. In other words, investment tends to be channelled through the knowledge derived primarily from past experience and learning rather than oriented to radical, often riskier, new market approaches. However, in a seemingly rapid changing business environment, the power to enable new businesses, new market approaches or new technologies, may well represent the difference between economic leadership and economic dependence, in the long run.

The fact that ownership concentration appears associated in France and Germany, for example, to financial systems strongly based in financial intermediaries, might suggest a risk minimisation attitude from the banks perspective when channelling investment to companies in the form of loans. This factor may, by itself, significantly influence the type of new investment performed in these economies, thus, in the limit, indirectly conditioning its specific economic growth rates. Exceptions to this do exist however, some of it in European companies such as Siemens, Philips and, more recently, Nokia, to mention just some cases.

In financial systems where financial markets are more developed, risk is widespread among a large community of investors, and higher profitability rates became a natural incentive for investors to partially support the higher risks associated with high-tech development, for example. Large investments in state-of-the-art technology do not seem to be incompatible with concentration ownership structures and systems where banks prevail over financial markets, they just naturally tend to be less frequent. In late years, 
countries like Japan and France have made an effort to move towards financial systems where stock markets may acquire a larger importance in the near future, which may be a point in favour to the prevalence of developed financial markets.

Also the degree to which investors are protected by legislation may be of crucial importance to the operation analysis of transmission mechanisms between financial structures and economy, as studied by Laporta, Lopez-de-Silanes, Shleifer and Vishny (1998). In common Law countries, such as the UK, stockholders and investors tend to be more protected than in countries of French legal tradition or even countries of German or Scandinavian legal tradition. Laporta et al. (1998) mention that a more satisfactory investor protection tends to appeal less to the necessity of ownership concentration, increasing companies access to external financing and reducing the costs of capital. Levine, Loyaza and Beck (2000) also mention efficiency of the legal systems regarding Law enforcement as of fundamental importance to promote investment. Countries where more efficient legal systems are present also tend to have more developed financial systems.

Also, the existence of rigorous rules regulating the companies release of high quality and comparable financial and accountability information also appears to be an important incentive to the promotion of investment, in general, and the development of financial systems, in particular. Allen and Gale (2000) have noted that the availability of quality financial information about companies has enabled the development of an active control market for companies (such as the existing in the US). These authors have claimed that the existence of such a market helps companies to adopt better investment decisions, rapidly distributing vital and comparable information among a large set of investors.

Despite all this, most authors keep in mind that economies of different companies in different stages of development represent specific problems, thus being inappropriate to generalise an ideal structure for the financial systems or to conceive a possible "general solution." According to Gerschenkron (1962) and Huang and Xu (1999) evidence exists for a decisive importance of banks during the early stages of economic development. However, a higher importance of financial markets is found for later stages of economic development. Differentiated phases of economic development seem to have differentiated funding needs. 


\section{Empirical Literature Review}

During the last years several empirical studies that focus on the relation between the development of financial systems and economic growth have been published. Levine (1999), Tsuru (2000), and Thiel (2001), present summaries of the relevant papers regarding the subject. Goldsmith (1969) provided one of the first econometric researches of the relation between financial development and economic development, suggesting a parallel between the development of financial systems and economy. ${ }^{8}$ By the end of the nineties, the array of research studies performed used mainly two econometric approaches: i) cross section/panel data analysis (for instance Bassanini et al. (2001) and Leahy et al. (2001)), and ii) co-integration and causality analysis (see for instance Rousseau and Wachtel (1998)).

The econometric studies based on cross section data have the purpose of investigating if there is a relation between representative variables of the financial system development and economic growth, measured as GDP growth, fixed capital formation or the productivity of production factors. Representative variables of the financial system are credit, intermediary margins, stock market capitalisation, and the volume of stock and other actives traded, among others. King and Levine (1993) found that the following variables were statistically significant when regressed towards real per capita GDP growth: net responsibilities as a percentage of GDP, bank credit divided by the deposits, credits of the central banks, and responsibilities of the private non-financial sector as a percentage of GDP. The problem of this type of studies, employing cross section data analysis is nevertheless the determination of the causality direction. Additionally, more recent studies using panel data analysis manage to investigate more accurately the relations involved, both in temporal and across time multiple countries data.

Additionally, Granger causality tests can also used to determine a more precise causality direction. Specifically Rousseau and Wachtel (1998) report a unique causality direction

\footnotetext{
8 Nevertheless, Levine (1999) and Thiel (2001) offer some criticisms of this research. According to these later authors, Goldsmith work did not clarify the issue of causality direction, if it is the development of financial systems that enables and eventually catalysis economic growth or the other way round. For a brief review of the theory of the finance-growth nexus, see also the two aforementioned authors.
} 
going from financial development to economic growth. A limitation of this study, however, is the reduced number of countries used in the data sample. Additionally, and also on related work, Rousseau and Wachtel (2002) report an inflation threshold beyond which the relationship between the size of a country's financial sector and its rate of economic growth ceases. Some of the relevant literature and its empirical findings are summarised in Table $1 .^{9}$

Table 1. The finance-growth nexus: empirical literature review

\begin{tabular}{|c|c|c|c|}
\hline Authors & $\begin{array}{l}\text { Countries/ } \\
\text { Period }\end{array}$ & Estimation Technique & Findings \\
\hline $\begin{array}{l}\text { Andrés, } \\
\text { Hernando and } \\
\text { López-Salino } \\
\text { (1999) }\end{array}$ & $\begin{array}{l}21 \text { OECD } \\
\text { countries } \\
(1961-1993)\end{array}$ & $\begin{array}{l}\text { Cross-country regression, } \\
\text { unrestricted VAR. }\end{array}$ & $\begin{array}{l}\text { Market capitalisation is the only } \\
\text { variable for which significance and } \\
\text { causality could be found }\end{array}$ \\
\hline $\begin{array}{l}\text { Bassanini, } \\
\text { Scarpetta and } \\
\text { Hemmings } \\
(2001)\end{array}$ & $\begin{array}{l}21 \text { OECD } \\
\text { countries } \\
(1971-1998)\end{array}$ & $\begin{array}{l}\text { Error correction panel regression, } \\
\text { pooled mean group estimators. }\end{array}$ & $\begin{array}{l}\text { Stock market significant in relation } \\
\text { to growth, bank credit only when } \\
\text { controlled for inflation variability. } \\
\text { Private credit and stock market } \\
\text { significant even after controlling for } \\
\text { investment. }\end{array}$ \\
\hline $\begin{array}{l}\text { Beck, Levine } \\
\text { and Loayza } \\
(2000)\end{array}$ & $\begin{array}{l}63 \text { countries } \\
(1960-1995)\end{array}$ & $\begin{array}{l}\text { Cross-country regression and } \\
\text { dynamic panel estimator. Control } \\
\text { variables: real GDP per capital, } \\
\text { average years of schooling, } \\
\text { inflation rate, openness, } \\
\text { government expenditure. }\end{array}$ & $\begin{array}{l}\text { Banks exert a strong, causal impact } \\
\text { on GDP growth and total factor } \\
\text { productivity growth. Results for } \\
\text { capital accumulation and savings } \\
\text { ratio are not robust or significant }\end{array}$ \\
\hline $\begin{array}{l}\text { Demirgüc- } \\
\text { Kunt and } \\
\text { Levine (1999) }\end{array}$ & $\begin{array}{l}150 \\
\text { countries } \\
(1990 \mathrm{~s})\end{array}$ & Correlation. & $\begin{array}{l}\text { In high-income countries, stock } \\
\text { markets are more active and efficient } \\
\text { relative to banks. }\end{array}$ \\
\hline $\begin{array}{l}\text { King and } \\
\text { Levine (1993) }\end{array}$ & $\begin{array}{l}80 \text { countries } \\
(1960-1989)\end{array}$ & Cross-country regression. & $\begin{array}{l}\text { Strong relationship between each } \\
\text { dependent variable and the financial } \\
\text { variables }\end{array}$ \\
\hline $\begin{array}{l}\text { Leahey, } \\
\text { Schich et al } \\
(2001)\end{array}$ & $\begin{array}{l}19 \text { OECD } \\
\text { countries } \\
(1970-1997)\end{array}$ & $\begin{array}{l}\text { Error correction panel regression } \\
\text { with different specifications to } \\
\text { account for country specific } \\
\text { effects. }\end{array}$ & $\begin{array}{l}\text { All financial variables significant for } \\
\text { pooled mean group estimator. Credit } \\
\text { and stock market significant even } \\
\text { with control for investment }\end{array}$ \\
\hline $\begin{array}{l}\text { Levine and } \\
\text { Zervos (1998) }\end{array}$ & $\begin{array}{l}49 \text { countries } \\
(1976-1993)\end{array}$ & $\begin{array}{l}\text { Cross-country regression } \\
\text { controlling for initial income, } \\
\text { inflation, government, social and } \\
\text { political variables. }\end{array}$ & $\begin{array}{l}\text { Correlation of stock market liquidity } \\
\text { and bank development with future } \\
\text { rates of economic growth. }\end{array}$ \\
\hline $\begin{array}{l}\text { Levine, } \\
\text { Loayza and } \\
\text { Beck }(2000)\end{array}$ & $\begin{array}{l}71 \text { countries } \\
(1960-1995)\end{array}$ & Cross-country regression. & $\begin{array}{l}\text { Exogenous component of financial } \\
\text { variables correlated with real } \\
\text { economic growth }\end{array}$ \\
\hline $\begin{array}{l}\text { Rousseau and } \\
\text { Sylla (2001) }\end{array}$ & $\begin{array}{l}17 \text { countries } \\
(1850-1997)\end{array}$ & Cross-country growth regressions. & $\begin{array}{l}\text { Financial variables important for } \\
\text { early development, best results for } \\
\text { period prior to } 1914 \text {, less important } \\
\text { for period after } 1945 \text {. }\end{array}$ \\
\hline
\end{tabular}

\footnotetext{
${ }^{9}$ A good survey of the empirical literature is also offered by Thiel (2001), both at the aggregate and at the industry and firm level.
} 
Table 1. (cont.)

\begin{tabular}{llll}
\hline $\begin{array}{l}\text { Rousseau and } \\
\text { Wachtel } \\
(1998)\end{array}$ & $\begin{array}{l}\text { USA, UK, } \\
\text { Canada, } \\
\text { Sweden, } \\
\text { Norway } \\
(1871-1929)\end{array}$ & $\begin{array}{l}\text { Granger causality in a VAR, vector } \\
\text { error correction model. }\end{array}$ & $\begin{array}{l}\text { Evidence of one-way causality from } \\
\text { finance to growth }\end{array}$ \\
\hline $\begin{array}{l}\text { Rousseau and } \\
\text { Wachtel }\end{array}$ & $\begin{array}{l}84 \text { countries } \\
(1960-1995)\end{array}$ & Cross-country regression. & Financial variables explain GDP. \\
\hline $\begin{array}{l}\text { Shan, Morris } \\
\text { and Sum }\end{array}$ & $\begin{array}{l}\text { 9 OECD } \\
\text { countries } \\
\text { (2001) }\end{array}$ & $\begin{array}{l}\text { Granger causality test, VAR } \\
\text { model. }\end{array}$ & $\begin{array}{l}\text { Causality runs from growth to } \\
\text { finance only in 3 countries. }\end{array}$ \\
\hline
\end{tabular}

\section{Panel Analysis: Financial Intermediaries versus Capital Markets}

In the present section we assess empirically the nexus finance-growth for the period between 1960 and 1999. The variables used to characterise a given country's financial system were domestic credit to private non-financial entities (also further referenced ahead as "credit") and the stock market capitalisation, or, in the absence of this data, stock transaction volume. We also use GDP at 1995 prices, measured in US dollars.

Table 2. Country panels

\begin{tabular}{|c|c|}
\hline Panels & Countries \\
\hline Developed Countries & $\begin{array}{l}\text { Austria, Belgium, Denmark, Finland, France, Germany, Greece, } \\
\text { Ireland, Italy, Japan, Luxembourg, Netherlands, Portugal, Spain, } \\
\text { Sweden, United Kingdom, USA }\end{array}$ \\
\hline Developing Countries & Argentina, Brazil, India, Malaysia, Mexico, Philippines, Thailand \\
\hline $\begin{array}{l}\text { Financial Intermediates } \\
\text { are dominant }{ }^{1}\end{array}$ & $\begin{array}{l}\text { Austria, Belgium, Finland, France, Germany, Greece, India, Italy, } \\
\text { Spain, Portugal }\end{array}$ \\
\hline $\begin{array}{l}\text { Financial Markets are } \\
\text { dominant }{ }^{1}\end{array}$ & Malaysia, Mexico, United Kingdom, USA \\
\hline Intermediate system ${ }^{1}$ & $\begin{array}{l}\text { Argentina, }^{2} \text { Brazil, }^{2} \text { Denmark, Ireland, Japan, Luxembourg, } \\
\text { Netherlands, Philippines, Sweden, Thailand }\end{array}$ \\
\hline
\end{tabular}

The panel sample of 25 countries is divided into developed and developing countries, and also segmented according to the dominance of intermediates or financial markets. 
Table 2 shows the aforementioned segmentations between developed and developing countries, and also between the countries were the financial system is assumed to be mainly consistent with financial intermediaries dominance or with capital markets dominance. Tsuru (2000) suggests this last classification.

\subsection{Credit Impact on GDP}

In order to assess the link between financial markets and growth we use panel data analysis. One of the advantages of using a panel data approach is that it allows the use of more observations and gives more degrees of freedom (see namely Hsiao (2002)). Another advantage may be the reduction of multicollinearity among variables.

The variable chosen as a proxy for the development of financial markets is stock market capitalisation. Credit to private non-financial entities is used as a proxy for the development of financial intermediaries. A linear model was used, as specified below:

$$
\Delta Y_{i t}=\gamma_{i}+\alpha\left(k_{1} \Delta X_{i t}+k_{2} \Delta Z_{i t}\right)+\beta Y_{i t-1}+u_{i t}
$$

where the subscripts $i$ and $t$ represent country and time, respectively, $\gamma$ is an unobserved country-specific effect, $Y$ is real GDP (constant 95 prices) in USD, $X$ and $Z$ are the values assumed by the proxy variables, respectively credit to private non-financial entities and stock market capitalisation, and $u$ is the error term. The dummy variables $k_{1}$ and $k_{2}$ assume the values 1 and 0 when the effect of credit on GDP is tested separately. These two variables change their assigned values when we want to assess the separate effect of market capitalisation on GDP $\left(k_{l}=0\right.$ and $\left.k_{2}=1\right)$. They both assume the value one when both proxies of financial system development are considered at the same time.

We present results for the pooled version, assuming that initial country specific effects, represented by the $\gamma_{i}$ coefficients, are all similar. We also report the results of both the fixed and random effects models, where the country specific effects vary from country to country. A usual F-test is used to select the most appropriate model between the 
pooled effects model and the fixed effects model. ${ }^{10}$ Additionally, the Hausman test is also computed to compare the fixed effects and the random effects models.

Table 3. Credit as a proxy for financial development: developed and developing countries $\left(k_{1}=1\right.$ and $\left.k_{2}=0\right)$

\begin{tabular}{|c|c|c|c|}
\hline & Pooled Effects & Fixed Effects & Random Effects \\
\hline \multicolumn{4}{|c|}{ panel 1 (all countries) } \\
\hline$\gamma($ constant $)$ & $\begin{array}{c}18511800000 \\
(8.92)^{* *}\end{array}$ & - & $\begin{array}{c}18978000000 \\
(2.71)^{* * *}\end{array}$ \\
\hline$\alpha$ (credit) & $\begin{array}{l}0.0643 \\
(1.73)^{*}\end{array}$ & $\begin{array}{c}0.0417 \\
(3.50)^{* *}\end{array}$ & $\begin{array}{c}0.0421 \\
(14.84)^{* *}\end{array}$ \\
\hline$\beta$ (lagged GDP) & $\begin{array}{c}0.0098 \\
(0.83)\end{array}$ & $\begin{array}{l}0.0031 \\
(1.74)^{*}\end{array}$ & $\begin{array}{c}0.0032 \\
(1.16)\end{array}$ \\
\hline $\mathrm{R}^{2}$ & 0.1969 & 0.6846 & 0.1958 \\
\hline $\mathrm{F}$ & - & $60.493 * *$ & - \\
\hline DW & 0.6962 & 1.4506 & 0.5393 \\
\hline Hausman Test & - & - & $\begin{array}{c}0.0012 \\
\mathrm{pv}=(0.9729)\end{array}$ \\
\hline $\mathrm{N}$ & & 888 & \\
\hline \multicolumn{4}{|c|}{ panel 2 (developed countries) } \\
\hline$\gamma($ constant $)$ & $\begin{array}{c}23978500000 \\
(8.34)^{* *}\end{array}$ & - & $\begin{array}{c}24165500000 \\
(2.49)^{*}\end{array}$ \\
\hline$\alpha$ (credit) & $\begin{array}{l}0.0630 \\
(1.74)^{*}\end{array}$ & $\begin{array}{c}0.0419 \\
(3.45)^{* *}\end{array}$ & $\begin{array}{c}0.0422 \\
(12.58)^{* *}\end{array}$ \\
\hline$\beta$ (lagged GDP) & $\begin{array}{c}0.0097 \\
(0.85)\end{array}$ & $\begin{array}{l}0.0030 \\
(1.70)^{*}\end{array}$ & $\begin{array}{c}0.0031 \\
(0.95)\end{array}$ \\
\hline $\mathrm{R}^{2}$ & 0.1973 & 0.6791 & 0.1960 \\
\hline $\mathrm{F}$ & - & $58.43 * *$ & - \\
\hline DW & 0.7025 & 1.4532 & 0.5509 \\
\hline Hausman Test & - & - & $\begin{array}{c}0.0011 \\
\mathrm{pv}=(0.9739)\end{array}$ \\
\hline $\mathrm{N}$ & & 615 & \\
\hline \multicolumn{4}{|c|}{ panel 3 (developing countries) } \\
\hline$\gamma($ constant $)$ & $\begin{array}{c}6463160000 \\
(9.90)^{* *}\end{array}$ & - & $\begin{array}{c}6499150000 \\
(3.79)^{* *}\end{array}$ \\
\hline$\alpha$ (credit) & $\begin{array}{c}0.0117 \\
(0.32)\end{array}$ & $\begin{array}{c}0.0088 \\
(0.22)\end{array}$ & $\begin{array}{c}0.0091 \\
(0.63)\end{array}$ \\
\hline$\beta$ (lagged GDP) & $\begin{array}{l}0.0233 \\
(2.29)^{*}\end{array}$ & $\begin{array}{l}0.0123 \\
(2.12)^{*}\end{array}$ & $\begin{array}{c}0.0135 \\
(1.40)\end{array}$ \\
\hline $\mathrm{R}^{2}$ & 0.0127 & 0.1892 & 0.0125 \\
\hline $\mathrm{F}$ & - & $10.755^{* *}$ & - \\
\hline DW & 1.1634 & 1.4209 & 1.1391 \\
\hline Hausman Test & - & - & $\begin{array}{c}0.000 \\
\mathrm{pv}=(0.9934)\end{array}$ \\
\hline $\mathrm{N}$ & & 272 & \\
\hline
\end{tabular}

Source: World Economic Indicator (2001).

$*$ and $* *$, statistically significant at the 5 and 1 per cent level respectively.

${ }^{10}$ The F statistic is computed as $F(n-1, n T-n-k)=\left[\left(R_{u}{ }^{2}-R_{p}{ }^{2}\right) /\left(1-R_{u}{ }^{2}\right)\right][(n T-n-k) /(n-1)]$, where $u$ stands for the model without restrictions, $p$ denotes the pooled regression, that is the model with the restriction that there is only one autonomous term, $n$ is the number of countries, $T$ is the number of periods and $k$ is the number of exogenous variables (see for instance, Greene (1997) and Johnston and DiNardo (1997)). 
Table 3 presents the results considering the entire country sample, panel 1, and considering the developed and developing countries segmentation, panels 2 and 3 respectively. Considering the proxy variable of financial development to be credit $\left(k_{l}=1\right.$ and $\left.k_{2}=0\right)$.

The results of the F-test performed indicate that the fixed effects model is more appropriate than the pooled effects model. On the other hand, the Hausman test indicates that the random effects model is preferable to the fixed effects model. Therefore, one may notice that in the random effects model, the proxy for financial development turns out to be statistically significant in explaining GDP only for the developed countries panel, and statistically not important for the developing countries sub-sample.

The non-significance of credit in explaining GDP growth in the developing countries is probably not surprising given the fragile organisation of financial intermediaries in those countries. Credit, though, is statistically significant for the entire country sample. The differences in the estimated coefficient and in the tests performed, between the two samples, are small. It seems therefore that considering the developing countries, alongside with the developed countries sample, does not change considerably the results. The overall results indicate that there is a direct relation between credit and GDP growth.

Taking into account the division of countries according to the type of the respective financial system, financial intermediaries dominance, financial markets dominance or intermediate system, the corresponding estimates are reported in Table 4.

Again, credit turns out to be an appropriate explanatory variable for GDP growth. Indeed, the credit coefficient is significant in all the three samples, regardless of the type of dominant financial system. Interestingly, the coefficient estimated for stock market based system countries is higher than the coefficient exhibited in bank-based and in intermediate system countries (see the random model results, the one that seems statistically more adequate). 
Table 4. Credit as a proxy for financial development: different financial systems $\left(k_{1}=1\right.$ and $\left.k_{2}=0\right)$

\begin{tabular}{lccc}
\hline & Pooled Effects & Fixed Effects & Random Effects \\
\hline \multicolumn{4}{c}{ panel 1 (bank-based systems) } \\
$\gamma$ (constant) & 10592200000 & - & 12234000000 \\
$\alpha$ (credit) & $(9.32)^{* *}$ & 0.0692 & $(3.656)^{* *}$ \\
& 0.1213 & $(1.23)$ & 0.0738 \\
$\beta$ (lagged GDP) & $(1.82)^{*}$ & 0.0029 & $(5.88)^{* *}$ \\
$\mathrm{R}^{2}$ & 0.0147 & $(1.02)$ & 0.0039 \\
$\mathrm{~F}$ & $(1.76)^{*}$ & 0.4191 & $(0.73)$ \\
$\mathrm{DW}$ & 0.1827 & 1.4230 & 0.1786 \\
Hausman Test & - & $17.363^{* *}$ & - \\
$\mathrm{N}$ & 1.1493 & - & 0.9513 \\
& - & 365 & 0.0072 \\
& & $\mathrm{pv}=(0.9327)$
\end{tabular}

\begin{tabular}{|c|c|c|c|}
\hline \multirow[t]{2}{*}{$\mathrm{N}$} & \multirow{2}{*}{\multicolumn{3}{|c|}{$\begin{array}{c}365 \\
\text { panel } 2 \text { (stock-market based systems) }\end{array}$}} \\
\hline & & & \\
\hline$\gamma$ (constant) & $\begin{array}{l}22737800000 \\
(5.53) * *\end{array}$ & $j$ & $\begin{array}{l}30733000000 \\
(1.76)^{*}\end{array}$ \\
\hline & 0.2732 & 0.1771 & 0.1823 \\
\hline$\alpha$ (credit) & $(8.36)^{* *}$ & $(6.31)^{* *}$ & $(10.61)^{* *}$ \\
\hline$\beta$ (lagged GDP) & 0.0053 & -0.0001 & 0.0002 \\
\hline $\mathrm{R}^{2}$ & $\begin{array}{l}(1.67)^{*} \\
0.5885\end{array}$ & $\begin{array}{l}(-0.10) \\
0.7508\end{array}$ & $\begin{array}{c}(0.04) \\
0.5868\end{array}$ \\
\hline $\mathrm{F}$ & - & $34.011^{* *}$ & $\begin{array}{c}0.0000 \\
-\end{array}$ \\
\hline DW & 1.3295 & 2.0036 & 1.0210 \\
\hline Hausman Test & - & - & $\begin{array}{c}0.0561 \\
\mathrm{pv}=(0.8127)\end{array}$ \\
\hline $\mathrm{N}$ & & 155 & \\
\hline \multicolumn{4}{|c|}{ panel 3 (intermediate systems) } \\
\hline$\gamma($ constant $)$ & $\begin{array}{c}16250100000 \\
(7.64)^{* * *}\end{array}$ & s.t. & $\begin{array}{c}15509100000 \\
(1.50)\end{array}$ \\
\hline$\alpha$ (credit) & $\begin{array}{c}0.0392 \\
(2.00)^{* *}\end{array}$ & $\begin{array}{c}0.0318 \\
(8.60)^{* *}\end{array}$ & $\begin{array}{c}0.0319 \\
(13.45)^{* *}\end{array}$ \\
\hline$\tau$ (lagged GDP) & $\begin{array}{c}0.0209 \\
(1.14)\end{array}$ & $\begin{array}{c}0.0026 \\
(0.82)\end{array}$ & $\begin{array}{c}0.0028 \\
(0.67)\end{array}$ \\
\hline $\mathrm{R}^{2}$ & 0.2057 & 0.7506 & 0.1936 \\
\hline $\mathrm{F}$ & - & $89.090 * *$ & - \\
\hline DW & 0.5034 & 1.3789 & 0.4121 \\
\hline Hausman Test & - & - & $\begin{array}{c}0.0010 \\
\mathrm{pv}=(0.9746)\end{array}$ \\
\hline $\mathrm{N}$ & & 366 & \\
\hline
\end{tabular}

Source: World Economic Indicator (2001).

* and ${ }^{* *}$, statistically significant at the 5 and 1 per cent level respectively.

\subsection{Stock Market Impact on GDP}

Tables 5 and 6 report the results using the same model as in the previous section. However, now the proxy variable used for the financial system is stock market capitalisation, in terms of the dummy variables in equation (1) this means setting up now $k_{1}=0$ and $k_{2}=1$. In table 5 , the full country sample is again divided into developed and developing countries. In table 6, the country sample is also segmented according to 
the type of financial system that predominates in each country. As in the previous subsection, the random effects model seems to be overall the more appropriate for the analysis of the influence of the proxy variable on GDP growth.

Table 5. Stock market capitalisation as proxy for financial development: developed and developing countries $\left(k_{l}=0\right.$ and $\left.k_{2}=1\right)$

\begin{tabular}{|c|c|c|c|}
\hline & Pooled Effects & Fixed Effects & Random Effects \\
\hline \multicolumn{4}{|c|}{ panel 1 (all countries) } \\
\hline$\gamma($ constant $)$ & $\begin{array}{c}21229500000 \\
(5.78)^{* *}\end{array}$ & - & $\begin{array}{c}21229900000 \\
(2.55)\end{array}$ \\
\hline$\alpha$ (capitalisation) & $\begin{array}{c}0.0875 \\
(3.38)^{* *}\end{array}$ & $\begin{array}{c}0.0324 \\
(1.55)\end{array}$ & $\begin{array}{c}0.0359 \\
(5.06)^{* *}\end{array}$ \\
\hline$\beta$ (lagged GDP) & $\begin{array}{c}0.0126 \\
(1.23)\end{array}$ & $\begin{array}{c}0.0003 \\
(0.08)\end{array}$ & $\begin{array}{c}0.0011 \\
(0.25)\end{array}$ \\
\hline $\mathrm{R}^{2}$ & 0.2146 & 0.6145 & 0.2089 \\
\hline $\mathrm{F}$ & - & $16.562 * *$ & - \\
\hline DW & 0.7369 & 1.2904 & 0.5364 \\
\hline Hausman Test & - & - & $\begin{array}{c}0.0314 \\
\mathrm{pv}=(0.8593)\end{array}$ \\
\hline \multicolumn{4}{|c|}{ panel 2 (developed countries) } \\
\hline$\gamma($ constant $)$ & $\begin{array}{c}24933000000 \\
(5.41)^{* *}\end{array}$ & - & $\begin{array}{c}10954700000 \\
(2.38)^{*}\end{array}$ \\
\hline$\alpha$ (capitalisation) & $\begin{array}{c}0.0851 \\
(3.27)^{* *}\end{array}$ & $\begin{array}{c}0.0324 \\
(1.54)\end{array}$ & $\begin{array}{c}0.0357 \\
(4.50)^{* *}\end{array}$ \\
\hline$\beta \quad$ (lagged GDP) & $\begin{array}{c}0.0126 \\
(1.25)\end{array}$ & $\begin{array}{c}0.0002 \\
(0.07)\end{array}$ & $\begin{array}{c}0.0011 \\
(0.2176)\end{array}$ \\
\hline $\mathrm{R}^{2}$ & 0.2060 & 0.6092 & 0.2000 \\
\hline $\mathrm{F}$ & - & $18.837 * *$ & - \\
\hline DW & 0.7364 & 1.2896 & 0.5460 \\
\hline Hausman Test & - & - & $\begin{array}{c}0.0295 \\
\mathrm{pv}=(0.8637)\end{array}$ \\
\hline $\mathrm{N}$ & & 275 & \\
\hline \multicolumn{4}{|c|}{ panel 3 (developing countries) } \\
\hline$\gamma($ constant $)$ & $\begin{array}{c}78937300000 \\
(6.24) * *\end{array}$ & - & $\begin{array}{c}82922300000 \\
(4.16)^{* *}\end{array}$ \\
\hline$\alpha$ (capitalisation) & $\begin{array}{l}0.0727 \\
(1.74)^{*}\end{array}$ & $\begin{array}{l}0.0787 \\
(1.89)^{*}\end{array}$ & $\begin{array}{l}0.0777 \\
(1.79)^{*}\end{array}$ \\
\hline b (lagged GDP) & $\begin{array}{c}0.0057 \\
(0.83)\end{array}$ & $\begin{array}{c}-0.0023 \\
(-0.62)\end{array}$ & $\begin{array}{c}0.0001 \\
(0.01)\end{array}$ \\
\hline $\mathrm{R}^{2}$ & 0.0088 & 0.2002 & 0.0054 \\
\hline $\mathrm{F}$ & - & $3.7525 * *$ & - \\
\hline DW & 1.0409 & 1.4043 & 1.0289 \\
\hline Hausman Test & - & - & $\begin{array}{c}0.00 \\
\mathrm{pv}=(1)\end{array}$ \\
\hline $\mathrm{N}$ & & 366 & \\
\hline
\end{tabular}

* and **, statistically significant at the 5 and 1 per cent level respectively.

The results of table 5 suggest a positive and statistically significant effect of stockmarket capitalisation on GDP growth, for developed and developing countries. One should nevertheless notice that the estimated coefficient is less statistically significant 
for developing countries than for the developed countries. This can be understood as evidence of the fact that developing countries are, in terms of financial development, in a previous level of development, with the banking sector providing most of the financing to the economy.

Table 6. Stock market capitalisation as a proxy for financial development: different financial systems $\left(k_{l}=0\right.$ and $\left.k_{2}=1\right)$

\begin{tabular}{|c|c|c|c|}
\hline & Pooled Effects & Fixed Effects & Random Effects \\
\hline \multicolumn{4}{|c|}{ panel 1 (bank-based systems) } \\
\hline$\gamma($ constant $)$ & $\begin{array}{c}14796100000 \\
(5.22)^{* *}\end{array}$ & - & $\begin{array}{c}15160700000 \\
(3.10)\end{array}$ \\
\hline$\alpha$ (capitalisation) & $\begin{array}{l}0.0647 \\
(2.46)^{*}\end{array}$ & $\begin{array}{c}-0.0101 \\
(-0.22)\end{array}$ & $\begin{array}{c}0.0036 \\
(0.11)\end{array}$ \\
\hline$\beta \quad$ (lagged GDP) & $\begin{array}{c}0.0078 \\
(1.64)\end{array}$ & $\begin{array}{c}-0.0058 \\
(-0.85)\end{array}$ & $\begin{array}{c}-0.0030 \\
(-0.39)\end{array}$ \\
\hline $\mathrm{R}^{2}$ & 0.0184 & 0.2549 & 0.0008 \\
\hline $\mathrm{F}$ & - & $6.0424 * *$ & - \\
\hline DW & 1.0074 & 1.3439 & $(0.9242)$ \\
\hline Hausman Test & - & - & $\begin{array}{c}0.1628 \\
\mathrm{Pv}=(0.6866)\end{array}$ \\
\hline \multicolumn{4}{|c|}{ panel 2 (stock-market based systems) } \\
\hline$\gamma($ constant $)$ & $\begin{array}{c}44854500000 \\
(3.41)^{* *}\end{array}$ & - & $\begin{array}{c}48264100000 \\
(1.38)\end{array}$ \\
\hline$\alpha$ (capitalisation) & $\begin{array}{c}0.1040 \\
(6.09)^{* *}\end{array}$ & $\begin{array}{l}0.05277 \\
(2.94)^{* *}\end{array}$ & $\begin{array}{c}0.0560 \\
(3.56)^{* *}\end{array}$ \\
\hline$\beta \quad$ (lagged GDP) & $\begin{array}{c}0.011 \\
(1.67)^{*}\end{array}$ & $\begin{array}{c}-0.0014 \\
(-0.51)\end{array}$ & $\begin{array}{c}-0.0005 \\
(-0.07)\end{array}$ \\
\hline $\mathrm{R}^{2}$ & 0.2890 & 0.6768 & 0.2712 \\
\hline $\mathrm{F}$ & - & $24.192 * *$ & - \\
\hline DW & 0.9144 & 1.7388 & 0.6684 \\
\hline Hausman Test & - & - & $\begin{array}{c}0.1412 \\
\mathrm{pv}=(0.7071)\end{array}$ \\
\hline $\mathrm{N}$ & & 61 & \\
\hline \multicolumn{4}{|c|}{ panel 3 (intermediate systems) } \\
\hline$\gamma($ constant $)$ & $\begin{array}{c}18567000000 \\
(3.84)^{* *}\end{array}$ & - & $\begin{array}{c}16484800000 \\
(1.49)\end{array}$ \\
\hline$\alpha$ (capitalisation) & $\begin{array}{c}0.0348 \\
(0.74)\end{array}$ & $\begin{array}{c}0.0095 \\
(0.27)\end{array}$ & $\begin{array}{c}0.0113 \\
(1.10)\end{array}$ \\
\hline$\beta$ (lagged GDP) & $\begin{array}{c}0.0164 \\
(1.51)\end{array}$ & $\begin{array}{c}0.0019 \\
(0.64)\end{array}$ & $\begin{array}{c}0.0030 \\
(0.46)\end{array}$ \\
\hline $\mathrm{R}^{2}$ & 0.0586 & 0.4770 & 0.0543 \\
\hline $\mathrm{F}$ & - & 13.086 & - \\
\hline DW & 0.5338 & 1.0075 & 0.4970 \\
\hline Hausman Test & - & - & $\begin{array}{c}0.0029 \\
\mathrm{pv}=(0.9570)\end{array}$ \\
\hline $\mathrm{N}$ & & 139 & \\
\hline
\end{tabular}

When the countries are divided according to the dominant financial system, stockmarket capitalisation has an unequivocally positive and statistically significant relation 
with GDP growth in countries where financial markets prevail as a source of funds (see panel 2 in Table 6). This result holds true for all the versions estimated, pooled, fixed and random effects.

Therefore, contrarily to the results obtained when credit was the proxy variable, stock market capitalisation is indeed only important for countries where the financial markets are dominant. For the bank-based systems and for the intermediate systems, stockmarket capitalisation seems to play a quite more mitigated role in explaining GDP growth since the estimated coefficients are virtually zero.

\subsection{Credit and Stock Market Capitalisation Impact on GDP Growth}

In this section, equation (1) is amended because we now want to use both stock market capitalisation and credit as explanatory variables of GDP, and we then have

$$
\Delta Y_{i t}=\gamma_{i}+\alpha_{1} \Delta X_{i t}+\alpha_{2} \Delta Z_{i t}+\beta Y_{i t-1}+u_{i t}
$$

The estimation results are presented in Table 7, with the country sample segmented between developed and developing countries, and in Table 8, dividing the countries according to the dominant financial system.

When we analyse the effect of both variables, used as proxy for the financial system development, on GDP growth, we find that, for the set of developing countries, only credit seems to be statistically significant (see panel 3 in Table 7). For the case of the developed countries, both credit and stock market capitalization have a positive influence on GDP growth. These results are in line with the conclusions already reported in the previous sub-sections. 
Table 7. Credit and stock market capitalisation: developed and developing countries

\begin{tabular}{|c|c|c|c|}
\hline & Pooled Effects & Fixed Effects & Random Effects \\
\hline \multicolumn{4}{|c|}{ panel 1 (all countries) } \\
\hline$\gamma($ constant $)$ & $\begin{array}{c}21510900000 \\
(6.27)\end{array}$ & - & $\begin{array}{c}20837000000 \\
(2.54)^{*}\end{array}$ \\
\hline$\alpha_{1}$ (credit) & $\begin{array}{l}0.0408 \\
(1.66)^{*}\end{array}$ & $\begin{array}{c}0.0345 \\
(4.29)^{* *}\end{array}$ & $\begin{array}{c}0.0348 \\
(8.87)^{* *}\end{array}$ \\
\hline$\alpha_{2}$ (stock market) & $\begin{array}{l}0.0660 \\
(2.50)^{*}\end{array}$ & $\begin{array}{c}0.0160 \\
(0.88)\end{array}$ & $\begin{array}{c}0.0188 \\
(2.75)^{* *}\end{array}$ \\
\hline$\beta \quad$ (lagged GDP) & $\begin{array}{c}0.0126 \\
(1.32)\end{array}$ & $\begin{array}{c}0.0010) \\
(0.30)\end{array}$ & $\begin{array}{c}0.0017 \\
(0.42)\end{array}$ \\
\hline $\mathrm{R}^{2}$ & 0.3161 & 0.6893 & 0.2745 \\
\hline $\mathrm{F}$ & - & $18.074 * *$ & - \\
\hline DW & 0.8646 & 1.4885 & 0.5659 \\
\hline Hausman Test & - & - & $\begin{array}{c}0.0410 \\
\mathrm{pv}=(0.9797)\end{array}$ \\
\hline $\mathrm{N}$ & & 331 & \\
\hline \multicolumn{4}{|c|}{ panel 2 (developed countries) } \\
\hline$\gamma($ constant $)$ & $\begin{array}{c}25552300000 \\
(5.86)^{* *}\end{array}$ & 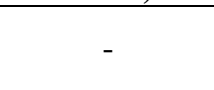 & $\begin{array}{c}25548200000 \\
(2.35)^{*}\end{array}$ \\
\hline$\alpha_{1}$ (credit) & $\begin{array}{l}0.0407 \\
(1.69)^{*}\end{array}$ & $\begin{array}{c}0.0345 \\
(4.30)^{* *}\end{array}$ & $\begin{array}{c}0.0348 \\
(7.90)^{* *}\end{array}$ \\
\hline$\alpha_{2}($ stock market $)$ & $\begin{array}{l}0.0637 \\
(2.42)^{*}\end{array}$ & $\begin{array}{c}0.0159 \\
(0.87)\end{array}$ & $\begin{array}{l}0.0186 \\
(2.42)^{*}\end{array}$ \\
\hline$\beta$ (lagged GDP) & $\begin{array}{c}0.0125 \\
(1.36)\end{array}$ & $\begin{array}{c}0.0009 \\
(0.28)\end{array}$ & $\begin{array}{c}0.0017 \\
(0.36)\end{array}$ \\
\hline $\mathrm{R}^{2}$ & 0.3096 & 0.6846 & 0.26998 \\
\hline $\mathrm{F}$ & - & $19.876^{* *}$ & - \\
\hline DW & 0.8656 & 1.4905 & 0.57844 \\
\hline Hausman Test & - & - & $\begin{array}{c}0.040190 \\
(0.9801)\end{array}$ \\
\hline $\mathrm{N}$ & & 258 & \\
\hline \multicolumn{4}{|c|}{ panel 3 (developing countries) } \\
\hline$\gamma($ constant $)$ & $\begin{array}{c}7167040000 \\
(5.24)^{* *}\end{array}$ & - & $\begin{array}{c}7567300000 \\
(3.66)^{* *}\end{array}$ \\
\hline$\alpha_{1}$ (credit) & $\begin{array}{c}0.1407 \\
(1.59)\end{array}$ & $\begin{array}{c}0.1616 \\
(1.66)\end{array}$ & $\begin{array}{l}0.1550 \\
(2.44)^{*}\end{array}$ \\
\hline$\alpha_{2}$ (stock market) & $\begin{array}{c}0.0499 \\
(1.40)\end{array}$ & $\begin{array}{l}0.0529 \\
(1.93)^{*}\end{array}$ & $\begin{array}{c}0.0533 \\
(1.24)\end{array}$ \\
\hline$\beta$ (lagged GDP) & $\begin{array}{c}0.0043 \\
(0.75)\end{array}$ & $\begin{array}{l}-0.0054 \\
(-1.78)^{*}\end{array}$ & $\begin{array}{c}-0.0028 \\
(-0.27)\end{array}$ \\
\hline $\mathrm{R}^{2}$ & 0.05019 & 0.2626 & 0.04512 \\
\hline $\mathrm{F}$ & - & $4.2654 * *$ & - \\
\hline DW & 0.9617 & 1.33399 & 0.9375 \\
\hline Hausman Test & - & - & $\begin{array}{c}0.0079 \\
\mathrm{pv}=(0.9290)\end{array}$ \\
\hline $\mathrm{N}$ & 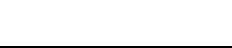 & 366 & \\
\hline
\end{tabular}

Using the segmentation of countries according to the dominant financial system, one can see that credit is relevant in explaining GDP, for the countries with bank-based systems (Table 8, panel 1). Also for this country sub-sample, stock-market capitalisation comes out as not statistically significant. For the stock market based 
systems, the number of observations is rather small (Table 8, panel 2), hampering therefore the possibility of getting any meaningful relation between the stock-market proxy and GDP growth. Nevertheless, credit still shows up as relevant in explaining GDP. Concerning the intermediate systems sub-sample, again only credit is important to establish the finance-growth nexus.

Table 8. Credit and stock market capitalisation: different financial systems

\begin{tabular}{|c|c|c|c|}
\hline & Pooled Effects & Fixed Effects & Random Effects \\
\hline \multicolumn{4}{|c|}{ Panel 1 (bank-based systems) } \\
\hline$\gamma$ (constant) & $\begin{array}{l}10928900000 \\
(4.52)^{* *}\end{array}$ & - & $\begin{array}{c}11848700000 \\
(3.29)^{* *}\end{array}$ \\
\hline$\alpha_{1}$ (credit) & $\begin{array}{l}0.2219 \\
(1.72)^{*}\end{array}$ & $\begin{array}{l}0.1717 \\
(1.35)\end{array}$ & $\begin{array}{c}0.1919 \\
(6.32)^{* *}\end{array}$ \\
\hline$\alpha_{2}$ (stock market) & $\begin{array}{l}-0.0258 \\
(-0.32)\end{array}$ & $\begin{array}{l}-0.0922 \\
(-1.12)\end{array}$ & $\begin{array}{c}-0.0683 \\
(-1.57)\end{array}$ \\
\hline$\beta$ (lagged GDP) & $\begin{array}{l}-0.0028 \\
(-0.26)\end{array}$ & $\begin{array}{c}-0.0108 \\
(-.89)\end{array}$ & $\begin{array}{l}-0.0076 \\
(-1.06)\end{array}$ \\
\hline $\mathrm{R}^{2}$ & 0.2955 & 0.3891 & 0.2839 \\
\hline $\mathrm{F}$ & - & $3.2308 * *$ & - \\
\hline DW & 0.9728 & 1.1294 & 0.8968 \\
\hline Hausman Test & - & - & $\begin{array}{c}2.2587 \\
\mathrm{pv}=(0.5205)\end{array}$ \\
\hline $\mathrm{N}$ & & 135 & \\
\hline \multicolumn{4}{|c|}{ panel 2 (stock market based systems) } \\
\hline$\gamma($ constant $)$ & $\begin{array}{l}30392500000 \\
(3.56)^{* *}\end{array}$ & & $\begin{array}{c}36066100000 \\
(1.99)^{* *}\end{array}$ \\
\hline$\alpha_{1}$ (credit) & $\begin{array}{l}0.357348 \\
(6.71)^{* *}\end{array}$ & $\begin{array}{c}0.2217 \\
(2.82)^{* *}\end{array}$ & $\begin{array}{c}0.2533 \\
(5.67)^{* *}\end{array}$ \\
\hline$\alpha_{2}$ (stock market) & $\begin{array}{l}-0.0796 \\
(-2.42)^{* *}\end{array}$ & $\begin{array}{c}-0.0439 \\
(-1.25)\end{array}$ & $\begin{array}{c}-0.0522 \\
(-2.17)^{* *}\end{array}$ \\
\hline$\beta$ (lagged GDP) & $\begin{array}{c}0.0081 \\
(1.39)\end{array}$ & $\begin{array}{c}0.0010 \\
(0.47)\end{array}$ & $\begin{array}{c}0.00278 \\
(0.46)\end{array}$ \\
\hline $\mathrm{R}^{2}$ & 0.6770 & 0.7674 & 0.6743 \\
\hline $\mathrm{F}$ & - & $8.3839 * *$ & - \\
\hline DW & 1.6900 & 2.1981 & 1.2809 \\
\hline Hausman Test & - & - & $\begin{array}{c}0.3836 \\
\mathrm{pv}=(0.8255)\end{array}$ \\
\hline $\mathrm{N}$ & & 61 & \\
\hline \multicolumn{4}{|c|}{ panel 3 (intermediate systems) } \\
\hline$\gamma$ (constant) & $\begin{array}{c}19317500000 \\
(4.51)^{* *}\end{array}$ & - & $\begin{array}{c}16546900000 \\
(1.45)\end{array}$ \\
\hline$\alpha_{1}$ (credit) & $\begin{array}{c}0.0301 \\
(2.24)^{* *}\end{array}$ & $\begin{array}{c}0.0311 \\
(8.48)^{* *}\end{array}$ & $\begin{array}{c}0.0311 \\
(9.68)^{* *}\end{array}$ \\
\hline$\alpha_{2}$ (stock market) & $\begin{array}{c}0.0185 \\
(0.45)\end{array}$ & $\begin{array}{c}-0.0077 \\
(-0.30)\end{array}$ & $\begin{array}{c}-0.0067 \\
(-0.82)\end{array}$ \\
\hline$\beta$ (lagged GDP) & $\begin{array}{c}0.0156 \\
(1.54)\end{array}$ & $\begin{array}{c}0.0008 \\
(0.32)\end{array}$ & $\begin{array}{c}0.0014 \\
(0.28)\end{array}$ \\
\hline $\mathrm{R}^{2}$ & 0.2555 & 0.7024 & 0.2117 \\
\hline $\mathrm{F}$ & - & $22.529 * *$ & - \\
\hline DW & 0.5208 & 1.2669 & 0.44078 \\
\hline Hausman Test & - & - & $\begin{array}{c}0.0024 \\
\mathrm{pv}=(0.9988)\end{array}$ \\
\hline $\mathrm{N}$ & & 133 & \\
\hline
\end{tabular}

Source: World Economic Indicator (2001).

* and **, statistically significant at the 5 and 1 per cent level respectively. 
One can naturally point some caveats concerning the analysis based on the division of countries according to the predominant financial intermediaries in a given country. Indeed, financial intermediaries also play an important role in the financial markets either as buyers of negotiable securities or as issuers of those same securities. This sort of activity is pursued side by side with the function of providing indirect financing to the economy, if we want to use the terminology of Gurley and Shaw)

\section{Conclusion and Summary}

This paper examined how the finance-growth nexus is affected by the so-called "predominant" financial system in a given country. For that purpose we used a panel data approach for a sample consisting of 24 countries throughout the 70s, 80s and 90s. As proxy for the bank-based "dominant" financial systems we used credit to the economy. As proxy for the stock market "dominant" financial systems we selected stock market capitalisation.

The results show that the credit variable is always significant in explaining GDP, regardless of the type of dominant financial system. When the countries are divided according to the "dominant" financial system, stock-market capitalisation also has an unequivocally positive and statistically significant relation with GDP growth in countries where financial markets prevail as a source for financing the economy. For the case of the developed countries both credit and stock market capitalization have a positive influence on GDP growth. However, for the set of developing countries, only credit seems to be statistically significant. The paper's findings are consistent with some of the results provided by previous empirical research with a similar study focus.

\section{References}

Allen, F. and Gale, D. (1995). "A welfare comparison of intermediaries and financial markets in Germany and the US," European Economic Review, 39 (2), 179-209.

Allen, F. and Gale, D. (2000). Comparing Financial Systems, MIT Press.

Andrés, J.; Hernando, I. And López-Salino, D. (1999). "The role of the financial system in the growth-inflation link: The OECD experience," Documento de Trabajo 9920, Banco de España. 
Bassanini, A.; Scarpetta, S. Hemmings, P. (2001). "Economic Growth: the role of policies and institutions; Panel data evidence from OECD countries," OECD Economics Department WP 283.

Carlin, W. and Mayer, C. (1999). "How do financial systems affect economic performance," Oxford Financial Research Centre WP 1999-FE-08.

Carlin, W. and Mayer, C. (2002). "Finance, investment and growth," Oxford Financial Research Centre WP 1999-FE-09.

Demirgüç-Kunt, A. and Levine, R. (1999). "Bank-based and market-based financial systems: cross-country comparisons," Working Paper 2143, World Bank.

Dewatripont, M. and Maskin, E. (1995). "Credit efficiency in centralized and decentralized economies," Review of Economic Studies, 62 (4), 541-555.

ECB (2002). Report on Financial Structures, European Central Bank,

Franks, J. and Mayer, C. (1998). "Ownership and Control in Europe," in Newman, P. (ed.), The new Palgrave Dictionary of Economics and the Law, Palgrave Publishers Ltd.

Fulghieri, P. and Rovelli, R. (1998). "Capital markets, financial intermediaries, and liquidity supply," Journal of Banking and Finance, 22 (9), 1157-1179.

Gershenkron, A. (1962). Economic backwardness in historical perspective, Cambridge, Harvard University Press.

Goldsmith, R. (1969). Financial structure and development, Yale University Press.

Greene, W. (1997). Econometric Analysis, 3rd ed., Prentice Hall.

Greenwood, J. and Janovic, B. (1990). "Financial Development, Growth and the Distribution of Income," Journal of Political Economy, 98 (5, Part 1), 1076-1107.

Hisao, C. (2002). Analysis of Panel Data, 2nd ed., Cambridge University Press.

Huang, H.; Xu, C. (1999). "Institutions, Innovations and Growth," American Economic Review, 89 (2), 438-433.

Jansen, M. and Murphy, K. (1990). "Performance Pay and Top Management Incentives," Journal of Political Economy, 98 (2), 225-264.

Johansen, S. (1991). "Estimation and Hypothesis Testing of Cointegration Vectors in Gaussian Vector Autoregressive Models," Econometrica, 59, 1551-1580.

Johnston, J. and DiNardo, J. (1997). Econometric Methods, McGraw-Hill. 
King, R. and Levine, R. (1993). "Financial Intermediation and Financial Development in Mayer, C. and Vives, X. (eds.) Financial Intermediation and the Construction of Europe, Centre for Economic Policy Research.

La Porta, R.; Lopez-de-Silanes, F.; Shleifer, A. and Vishny, R. (1998). "Law and Finance," Journal of Political Economy, 106 (6), 1113-1155.

Leahy, M.; Schich, S.; Wehinger, G.; Pelgrin, F. and Thorgeirsson, T. (2001). "Contributions of Financial Systems to Growth in OECD Countries," OECD Economics Department WP 280.

Levine, R. (1997). "Financial Development and Economic Growth: Views and Agenda," Journal of Economic Literature, 35 (3), 688-726.

Levine, R. (1999). "Bank-Based and Market-Based Financial Systems: Cross-Country Comparisons ," World Bank Working Paper 2143.

Levine, R. and Zervos, S. (1998). "Stock Markets, Banks and Economic Growth," American Economic Review, 88 (3), 537-558.

Levine, R.; Loayza, N. and Beck, T. (2000). "Financial Intermediation and Growth: Causality and Causes," Journal of Monetary Economics, 46 (1), 31-77.

Qi, J. (1994). "Bank Liquidity and Stability in an Overlapping-generations Model," Review of Financial Studies, 7 (2), 389-417.

Rousseau, P. and Sylla, R. (2001). "Financial Systems, Economic Growth, and Globalisation,'Working Paper 8323 NBER.

Rousseau, P. and Wachtel, P. (1998). "Financial Intermediation and Economic Performance: Historical Evidence from Five Industrialized Countries," Journal of Money, Credit, and Banking, 30 (4), 657-678.

Rousseau, P. and Wachtel, P. (2002). "Inflation thresholds and the finance-growth nexus," Journal of International Money and Finance, 21 (6), 777-793.

Shan, J.; Morris, A. and Sun, F. (2001). "Financial development and economic growth: an egg and chicken problem?" Review of International Economics 9 (3), 443-454.

Sharpe, S. (1990). "Asymmetric Information, Bank Lending, and Implicit Contracts: a Stylized Model of Customer Relationships," Journal of Finance, 45 (4), 1069-1087.

Sirri, E. and Tufano, P. (1995). "The Economics of Pooling," in Crane, D. et al., (ed.) The Global Financial System: A Functional Perspective, Harvard Business School Press: Cambridge.

Stiglitz, J. (1985). "Credit Markets and the Control of Capital," Journal of Money, Credit and Banking, 17 (2), 133-152. 
Stulz, R. (2000). "Does Financial Structure Matter for Economic Growth? A Corporate Finance Perspective," mimeo, conference paper, Financial Structure and Economic Development Conference, February 10-11, 2000, World Bank, Washington, D.C.

Thiel, M. (2001). "Finance and Economic Growth - a Review of Theory and the Available Evidence", Economic Papers 158, European Commission.

Tsuru, K. (2000). "Finance and Growth: Some Theoretical Considerations, and a Review of the Empirical Literature," OECD Economics Department WP 228.

\section{Annex - Data sources}

\begin{tabular}{|c|c|c|}
\hline Data & Period & Source \\
\hline $\begin{array}{l}\text { GDP } \\
\text { (constant } \\
1995 \text { USD) }\end{array}$ & $\begin{array}{l}\text { - From } 1970 \text { to } 1999 \text { for Germany and from } 1960 \text { to } \\
1999 \text { for the rest of the countries. }\end{array}$ & $\begin{array}{l}\text { World Bank, World } \\
\text { Development } \\
\text { Indicators, } 2001\end{array}$ \\
\hline $\begin{array}{l}\text { Credit to the } \\
\text { Private } \\
\text { Sector } \\
\text { (Constant } \\
\text { 1995 USD) }\end{array}$ & $\begin{array}{l}\text { - From } 1960 \text { to } 1999 \text { except for some of the developed } \\
\text { countries. } \\
\text { - 1970-1998 in the case of Austria, Belgium, France and } \\
\text { Netherlands. } \\
\text { - 1960-1998 for Finland, Ireland, Portugal and Spain } \\
\text { 1960-1998. } \\
\text { - Italy 1963-1998, Luxembourg 1977-1997 and } \\
\text { Germany 1970-1998. }\end{array}$ & $\begin{array}{l}\text { World Bank, World } \\
\text { Development } \\
\text { Indicators, } 2001 . \\
\text { Data for Germany from } \\
1970 \text { to } 1990 \text { inclusive } \\
\text { base on IMF. Data for } \\
\text { West Germany: } \\
\text { International Financial } \\
\text { Statistics Yearbook, } \\
\text { 1998, 1999, } 2000 .\end{array}$ \\
\hline $\begin{array}{l}\text { Stock Market } \\
\text { Capitalizatio } \\
\text { n (Constant } \\
1995 \text { USD) }\end{array}$ & $\begin{array}{l}\text { - From } 1980 \text { to } 1999 \text { according to the availability of data } \\
\text { for each of the countries. } \\
\text { - 1980-1999 inclusive in the case of Austria, Belgium, } \\
\text { Denmark, France, Germany, Ireland, Italy, Japan, } \\
\text { Netherlands, United Kingdom, United States. - Sweden } \\
\text { (1982-1999). } \\
\text { - Malaysia (1986-1999). } \\
\text { - Philippines, Spain and Thailand (1987-1999). } \\
\text { - Argentina, Greece, Finland and Mexico (1988-1999). } \\
\text { - India and Portugal (1990-1999). } \\
\text { - Luxembourg (1992-1999). } \\
\text { - Brasil (1994-1999). }\end{array}$ & Datastream. \\
\hline
\end{tabular}

